\title{
Effect of increasing inoculum ratio on energy recovery from chicken manure for better use in Egyptian agricultural farms
}

\author{
Ouahid Elasri ${ }^{{ }^{*}+} \mathbb{B}$, Mahmoud Salem ${ }^{2 \dagger}$, Mohamed Ramdani ${ }^{3}$, Oulya Zaraali ${ }^{4}$ and Latrach Lahbib ${ }^{5}$
}

\begin{abstract}
Background: Poultry production is one of the fastest growing agricultural activities in Egypt. This activity is delivering large quantities of chicken manure. This organic waste can have a negative impact on the environment and public health in the vicinity of the Egyptian agricultural farms. In this study, we treated this organic waste by anaerobic digestion for achieving the maximum production of biogas with a high percentage of methane. For this, we investigated the different ratio of bacterial inoculum and manure chicken content.

Methods: Seven anaerobic mixtures with different inoculums (1:1, 1:2, 1:3, 1:4, 1:5, 1:6 and 1:7) were tested. All digesters are placed in a constant temperature $35^{\circ} \mathrm{C}$. Biogas and methane production during 50 days of incubation.

Results: The best ratio in terms of biogas produce is the low ratio (1:7) with a production of $73.3 \mathrm{Nml} / \mathrm{gVS}$. But from a qualitative point of view, the largest ratio (1:1) was delivering a biogas with the highest calorific value in terms of methane content with $69.9 \%$ of biogas.

Conclusions: The energy valorization of chicken manure depends on the waste/inoculum ratio. The maximum biogas produced is using the lowest ratio of waste and inoculum (1:7) but the highest methane percentage in the biogas is reached by the highest of ratio (1:1). Thus, from a qualitative point of view, the high percentage of methane is obtained for the highest ratio 1:1, however, from a quantitative point of view, the largest production is obtained from the lowest ratio 1:7.
\end{abstract}

Keywords: Anaerobic digestion, Biogas, Manure chickens, methane, ratio, Calorific value

\section{Background}

Poultry production has been one of the fastest growing agricultural activities in Egypt. The poultry sector employment represents approximately $6 \%$ of Egypt's 23.7 million labor force in 2003 and more than $15 \%$ of the agricultural work force [1]. In 2014, this country has produced 140 millions chicken heads [2]. The growth of this Egyptian activity leads to increasing quantities of chicken manure in farms and breeding units. Therefore, this large production of chicken meat produces large quantities of organic wastes.

\footnotetext{
*Correspondence: elasriouahid@yahoo.fr

${ }^{\dagger}$ Ouahid Elasri and Mahmoud Salem contributed equally to this work 1 Biochemistry and Biotechnology Laboratory, Mohamed First University, Oujda, Morocco

Full list of author information is available at the end of the article
}

This waste must be strictly managed according to the governmental regulations because it delivers high content of nitrogen and pathogenic bacteria, mainly staphylococci and enterobacteriaceae [3, 4]. These quantities of bacteria and nitrogen can be lost through lixiviation or runoff and will be retrieved in groundwater and surface water, causing diseases or epidemics $[5,6]$. It is involved too in the production of greenhouse gas, with the big emission factor $\left(0.023 \mathrm{~kg} \mathrm{head}^{-1}\right.$ year $\left.^{-1}\right)$ [7]. Thus, the chicken manure has a negative impact on the environment and public health.

In other hand, Egypt was exposed to repeated electricity failures because of a combination of increasing demand, natural gas supply shortages, old infrastructure, insufficient generation and transport infrastructure. In addition to that, this country has become dependent on 
hydrocarbon imports. Consequently, this energy deficit has a negative impact on economical trade balance and the country budget [8].

In front of these two problems, the progressive production of chicken's manure and the energy deficit is an ideal situation to develop a green technology that combines valorization of waste and production of energy. Among the current technologies, anaerobic digestion is gaining more importance across the world, thanks to its efficiency as a green treatment [9]. This process is based on the degradation of various organic wastes and substrates in hermetically closed digester $[10,11]$. These organic wastes are partially converted by microorganisms to biogas $[12,13]$.

Biogas is a renewable alternative fuel for internal combustion engines that has several advantages over conventional fuels, including lower costs, reduced levels of harmful emissions and being carbon neutral [14]. Thus, the biogas is delivering energy by cogeneration motor able to supply the farms and the breeding units in green energy [15].

In this work, we treated this Egyptian organic waste by anaerobic digestion. Precisely, we have studied the different ratios of waste and inoculum for producing the ideal quantity of biogas favoring a large high calorific value. This study is the first attempt to study the ratio of waste and inoculum in the Egyptian area.

\section{Methods}

\section{Chicken manure and inoculum}

Chicken manure contains manure droppings and bedding material. Taken from a commercial poultry farm housing with 6000 broilers per cycle, with an annual manure production 14 tons at Sharqia governorate in Egypt. This organic waste is collected in a 20-1 plastic bucket with tight lids, and immediately stored in a freezer at $-20^{\circ} \mathrm{C}$ in the laboratory.

The inoculum used in this work is obtained after 50 days of anaerobic digestion of cattle manure at mesophilic condition $\left(35^{\circ} \mathrm{C}\right)$ in our laboratory. All the organic matters in this inoculum are exhausted and the bacteria are very activated [16]. The compositions of chicken manure and inoculum are summarized in Table 1.

\section{Laboratory experiments}

In this work, eight anaerobic digestion tests were conducted: 1 control (inoculum only) and 7 experimental (waste with different quantity of inoculum). These tests are based on completely randomized design. The use of a control test allowed us to set up the deduction of the amount of biogas production by the residual organic matter in the inoculum alone. The experimental tests have included the combination of seven different ratios (1:1, 1:2, 1:3, 1:4, 1:5,
Table 1 Characterization of substrates and inoculum

\begin{tabular}{llll}
\hline Parameter & Unit & Chicken manure & Inoculum \\
\hline Water content & $\mathrm{g}$ & $26.89 \pm 0.4$ & $95.88 \pm 0.3$ \\
Total solid & $\mathrm{g} / 100 \mathrm{~g}$ & $73.11 \pm 0.2$ & $04.12 \pm 0.1$ \\
Volatile solid & $\mathrm{g} / 100 \mathrm{~g}$ & $81.43 \pm 0.2$ & $77.78 \pm 0.1$ \\
Total carbon & $\mathrm{g} / 100 \mathrm{~g}$ & $47.23 \pm 0.2$ & $45.11 \pm 0.1$ \\
Total Kjeldahl nitrogen & $\mathrm{g} / 100 \mathrm{~g}$ & $02.99 \pm 0.3$ & $01.70 \pm 0.1$ \\
$\mathrm{C} / \mathrm{N}$ ratio & - & $16: 1$ & $27: 1$ \\
$\mathrm{pH}$ & - & $08.89 \pm 0.2$ & $08.75 \pm 0.1$
\end{tabular}

Mean values originated from three independent replications with standard deviations

1:6 and 1:7) of poultry manure and inoculum, respectively, without dilution with water (Table 2). The tests were prepared with a balance to allow the mass balance by grams, and we assumed an inoculum density of 1 [17]. Consequently, each experimental test had different $\mathrm{C} / \mathrm{N}$ ratio ranged from 16 to 17.5 and a total solid content ranged from 14 to $32 \%$. Each test was replicated twice.

\section{Digesters}

The eight types of digesters used in this work are conical flasks of $500 \mathrm{ml}$. Each digester was sealed with a rubber stopper and connected via its biogas outlet to a $100-\mathrm{ml}$ burette glass collecting apparatus (Fig. 1). The fabricated biogas collecting device has a valve which was used to run-off the process.

All digesters are placed in automatically controlled temperature water bath, with a constant temperature of $35^{\circ} \mathrm{C}$. The agitation of these digesters is manually performed for $30 \mathrm{~s}$ only once a day for two reasons, (i) to achieve a contact between the microorganisms and waste, and (ii) to prevent scum formation. The dry anaerobic digestion is performed during 50 days per batch mode.

\section{Measurement and analysis of biogas production}

Every day, we followed the biogas production by moving acidified saline water in a graduated and an inverted burette connected to the digester [18]. The volumes of biogas produced were adjusted to the standard conditions of pressure and temperature [19].

The content of methane $\left(\mathrm{CH}_{4}\right)$ in biogas product was determined as follows. A known volume of the biogas produced $\left(\mathrm{V}_{1}\right)$ in a digester was syringed out and injected into serum bottle which contained $20 \mathrm{~g} \mathrm{l}^{-1}$ of $\mathrm{KOH}$ solution (Fig. 2). This serum bottle was shaken manually for 3-4 min so that all the $\mathrm{CO}_{2}$ and $\mathrm{H}_{2} \mathrm{~S}$ was absorbed by $\mathrm{KOH}$ solution [20]. The volume of the remaining biogas $\left(\mathrm{V}_{2}\right)$ which was $99.9 \% \mathrm{CH}_{4}$ in the serum bottle was determined by means of a syringe. The percentage of the report $\left(\mathrm{V}_{2} / \mathrm{V}_{1}\right)$ provided the content of $\mathrm{CH}_{4}$ in this biogas production [21]. 
Table 2 Experimental protocol for preparing the eight digesters

\begin{tabular}{llcccc}
\hline $\begin{array}{l}\text { Ration waste/ } \\
\text { inoculum }\end{array}$ & Poultry manure $(\mathbf{g})$ & Inoculum $(\mathbf{g})$ & Water $(\mathbf{g})$ & C/N ratio & Initial TS (\%) \\
\hline $1: 1$ & $40 \pm 0.1$ & $40 \pm 0.1$ & 0 & 16.13 & $32.66 \pm 0.2$ \\
$1: 2$ & $40 \pm 0.1$ & $80 \pm 0.1$ & 0 & 16.44 & $27.44 \pm 0.2$ \\
$1: 3$ & $40 \pm 0.1$ & $120 \pm 0.1$ & 0 & 16.74 & 17.02 \\
$1: 4$ & $40 \pm 0.1$ & $160 \pm 0.1$ & 0 & 17.28 & $17.85 \pm 0.2$ \\
$1: 5$ & $40 \pm 0.1$ & $200 \pm 0.1$ & 0 & 17.53 & $17.00 \pm 0.2$ \\
$1: 6$ & $40 \pm 0.1$ & $420 \pm 0.1$ & 0 & 17.76 & $14.41 \pm 0.2$ \\
$1: 7$ & $40 \pm 0.1$ & $280 \pm 0.1$ & 0 & 0.2 & 0.2 \\
\hline
\end{tabular}

Mean values originated from three independent replications with standard deviations

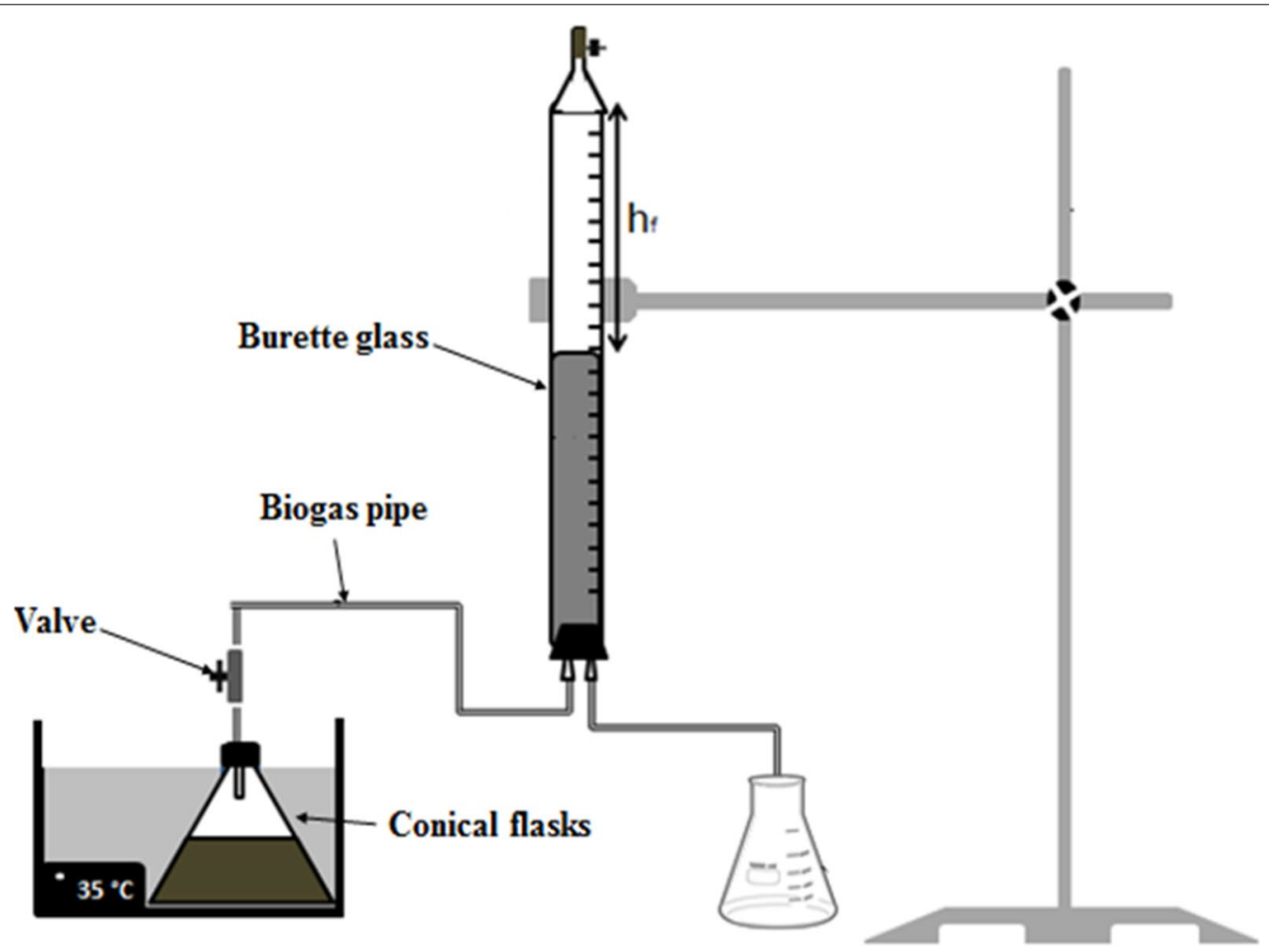

Fig. 1 Measurement of biogas production, (hf: Moving the measurement solution)

\section{Chemical analyses}

Total solids (TS) and volatile solids (VS) are considered as the most important qualitative and quantitative criteria for an organic waste treated by anaerobic digestion. The TS was performed according to the standard protocol which consists of drying the fresh matter (FM) at $105{ }^{\circ} \mathrm{C}$ to a constant weight. The VS is a gravimetric method based on the mass loss of the dry sample (sample from the determination of TS) in a muffle furnace at $550{ }^{\circ} \mathrm{C}$ for $6 \mathrm{~h}$ [22].

We measured the $\mathrm{pH}$ in digesters with a $\mathrm{pH}$ meter (WTW 720 handheld pH meter, Germany), which was calibrated by both standards $(\mathrm{pH}=4$ and $\mathrm{pH}=7)$. The $\mathrm{pH}$ was determined two times: The start of tests $\left(\mathrm{pH}_{\mathrm{i}}\right)$ to verify the beginning of the anaerobic digestion and at the end of tests $\left(\mathrm{pH}_{\mathrm{f}}\right)$, i.e., after the 50 days period of anaerobic digestion.

\section{Statistical analysis}

All data collected of this work were subjected to statistical analysis using Statistical Package for the Social Sciences (SPSS). We started these analyses with the Levene test to determine the homogeneity of the variance 


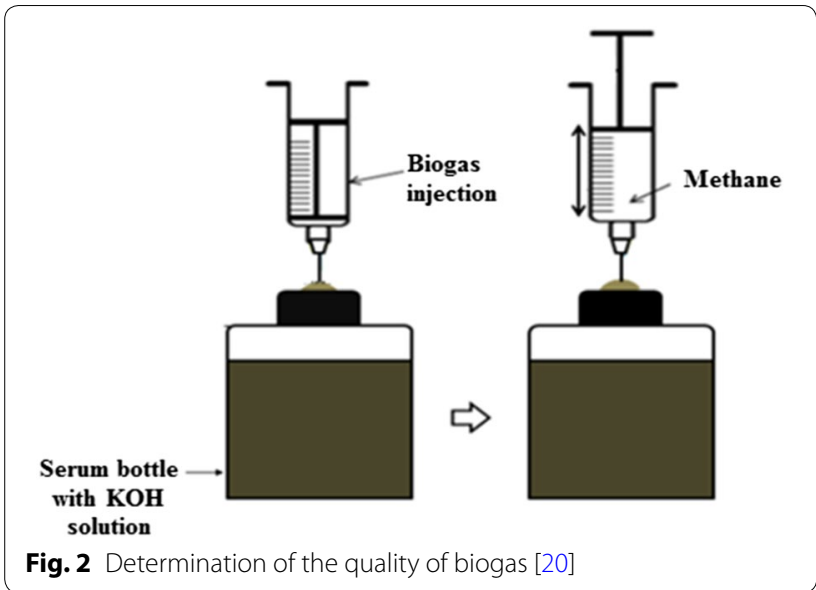

(Homoscedasticity). Then, we performed one-way analysis of variance (ANOVA) to determine the significant differences for the different parameters (biogas, methane yield and $\mathrm{pH}$ ). Moreover, the Duncan's multiple range tests were used to establish which ratio is significantly important.

\section{Results and discussion Statistical analysis}

Table 3 illustrates the analysis of variance of methane production, biogas yield and $\mathrm{pH}$. The variances are homogeneous (verified by the Levene test). Thus, we opt for the ANOVA test. This last test shows that the $p$ values are all less than $0.001(p<0.001)$, which allows us to conclude that the differences observed at the level of methane production, the biogas yield and the fluctuation of the $\mathrm{pH}$ are statistically significant.

\section{Comparison of the biogas potential produced}

After 50 days of incubation, we observed that all ratios of waste and inoculum did produce biogas. The lowest among these ratios (1:7) is the most important ratio in terms of the quantitative amount of biogas produced 73.3 $\mathrm{Nml} / \mathrm{gVS}$ compared to other ratios (Fig. 3). As well as the comparison of means by Duncan test showed that there has a significant increase in quantity of biogas in the ratio (1:7).

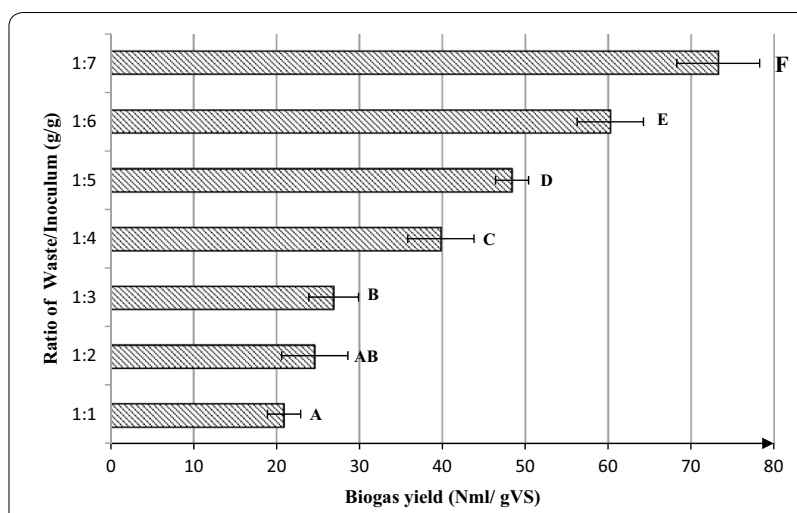

Fig. 3 Comparison of the biogas potential produced by different ratios. Mean values originated from three independent replications. Horizontal bars represent standard deviations. Means with different letters indicate significant differences (Duncan's Test $p<0.05$ )

We also note that the largest $\mathrm{C} / \mathrm{N}$ ratio (17.76) belongs to this ratio (1:7). Therefore, this biogas is correlated with an excellent $\mathrm{C} / \mathrm{N}$ ratio. Thus, the latter provides an excellent supply of carbon and nitrogen for the bacterial arsenal [23]. The increase of the waste and inoculum ratio (1:1) leads to two types of inhibition: The first type is by production of ammonia because the introduction of a large amount of nitrogenous substrate in the digester. Abouelenien et al. (2010) confirmed that this ratio of chicken manure and inoculum (1:1) produces a large fraction of ammonium causing a low production of biogas [24]. This ammonia $\left(\mathrm{NH}_{4}{ }^{+}\right)$product at a deamination during digestion anaerobic, it is able to diffuse passively into the inoculum bacteria mainly the methanogens thanks to its hydrophobic character, creating a proton imbalance [9], leading to a loss of potassium [25] and blocking enzymatic reactions [26]. The second type due to the accumulation of volatile fatty acids (VFAs) resulting from the biodegradation anaerobic of this waste. This is because of the transport and transformation's mechanisms from liquid phase to solid and biological degradation of VFAs is becoming difficult [24, 25]. Hwu et al. [29] recommended that the transportation limitations were causing sludge floatation resulting from adsorption of the long chain of fatty acids into cell walls. Finally, the

Table 3 Analysis of variance of methane production, biogas yield and $\mathrm{pH}$

\begin{tabular}{lllcc}
\hline & Degrees of freedom & Sum of squares & Mean squares & $\boldsymbol{F}$ \\
\hline Methane production & 6 & 1405.9 & 234.3 & $101.68^{* * *}$ \\
Biogas yield & 6 & 7011 & 1168.4 & $160.9^{* * *}$ \\
$\mathrm{pH}$ & 6 & 1.736 & 0.289 & $62.12^{* * *}$ \\
\hline
\end{tabular}

*** $p<0.001$ 
percentage of waste having access to the cells of inoculum has restricted the production of biogas [30].

On the other hand, this low ration (1:7) contains a small fraction in TS (14.78\%) which leads to a low approval in organic matter and nitrogen (Table 2). Thus, this ratio does not exhibit inhibition by ammonium or volatile fatty acids. The lower ratio of waste and inoculum indicates also a lower quantity of ammonia and VFAs within the microorganism present in digester. Thus, the existence of a higher inoculum quantity than organic waste dedicated to the valorisation by anaerobic digestion may dilute the ammonia and VFAs [24-31]. This low ratio also indicated a higher adaptation of microorganism to the substrate content resulting in a higher biogas yield [32].

Some researchers states that this low biogas production may be due to imbalances of hydrolytic, fermentative, and acetogenic bacteria, and methanogenic archaea [33]. Generally, these imbalances are caused by improper $\mathrm{C} / \mathrm{N}$ ratio, accumulation of VFAs, and high content of total ammonia-nitrogen and free ammonia concentration $[34,35]$. Finally, the $1: 7$ ratio is the optimal ratio for the production of biogas from chicken droppings. On the other hand, the important inoculum load reduces the risk for the installation of inhibition. These results are similar to work such as Neves at 2004, which confirmed that the low ratio is better for anaerobic digestion of other organic waste and substrate [36].

\section{Comparison of the biogas quality produced}

The comparison of means by Duncan test showed that the ratio (1:1) has a significant content of methane in biogas produced. Thus, we noted that the high ratio (1:1) has the highest methane content (69.9\%) compared with the other ratio studied (Fig. 4).

Therefore, the ratio $1: 1$ is the most important qualitative ratio because it produces a biogas with a large high

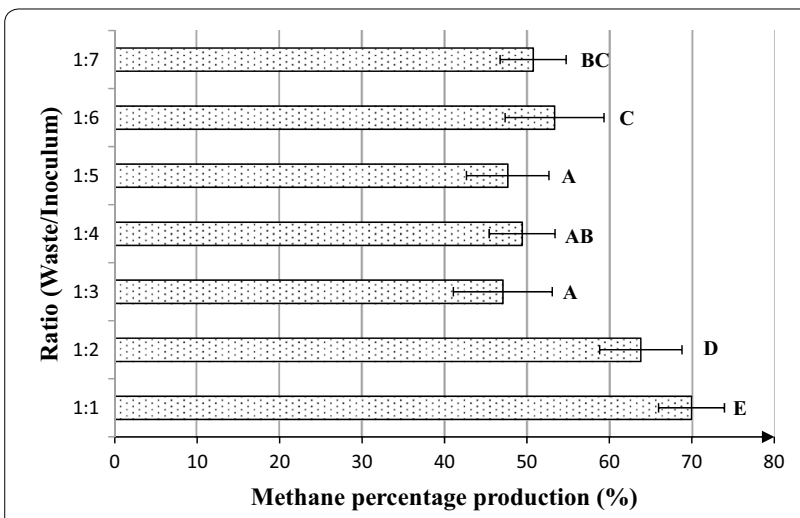

Fig. 4 Comparison of the methane percentage in biogas produced by different ratios of waste/inoculum. Mean values originated from three independent replications. Horizontal bars represent standard deviations. Means with different letters indicate significant differences (Duncan's test $p<0.05$ ) calorific value of order $\left(6.9 \mathrm{kWh} / \mathrm{m}^{3}\right)$. We have already noticed that this large ratio is producing the lowest production of biogas but with an excellent quality.

This big production of methane in low biogas production is indicated by the occurrence of few survivals of the anaerobic consortium that are able to digest the accumulated long chain of fatty acids and to reproduce the methane [30]. Nazaitulshila [37] described the same result, by studying the fat and oils where the increase in the ratio to 1:1 makes it possible and has recorded a large percentage of methane. The other researcher such as Chynoweth [38] reported that a maximal methane yields were obtained with ratio of waste and inoculum between 1:2 and 1:1 in anaerobic batch digestion of herbaceous, woody feedstock and municipal wastes [39]. Based on a volatile solid, Li et al. [40] have demonstrated that higher cumulative methane production was observed for the 1:1 ratio of waste and inoculum, when kitchen waste was used as a substrate. Finally, the high ratio of waste and inoculum (1:1) influences methane yields for this organic waste.

\section{The evolution of $\mathrm{pH}$}

We observed that all the ratios in this work showed a decrease of the $\mathrm{pH}$ level at the end of the anaerobic digestion except for the high ratio (1:1) which showed a $\mathrm{pH}$ increase (Fig. 5). The decrease of $\mathrm{pH}$ in the ratios $(1: 2-1: 7)$ is due to the production of organic metabolites in four steps of anaerobic digestion of this waste [41]. On the other hand, the increase of $\mathrm{pH}$ in the ratio 1:1 is due to ammonia-nitrogen $\left(\mathrm{NH}_{3}-\mathrm{N}\right)$ concentration could contribute to the alkalinity and could help to maintain the $\mathrm{pH}$ value [42]. But the excess of ammonium can inhibit the destruction of organic compounds, the production of volatile fatty acids and methanogenesis activities [43]. Therefore, this result explains the low production of biogas by the high ratio (1:1).

The ratio 1:7 shows a slight decrease in $\mathrm{pH}$ from 7 to 6.93 but this low fall remains in the optimal interval of the biogas production [44]. Finally, the treatment of chicken manure is done according to the intended use, if we want a large production of biogas with a low-calorific value is used the ratio 1:7 but if we need a biogas of small quantity and with a large calorific value we used the large 1:1 ratio.

\section{Conclusion}

The treatment of Egyptian manure chicken by anaerobic digestion is feasible and positively recommended. The use of an optimum waste/inoculum ratio is essential for the best energetic valorization of this type of organic waste because the ratio of waste/inoculum is impacting 


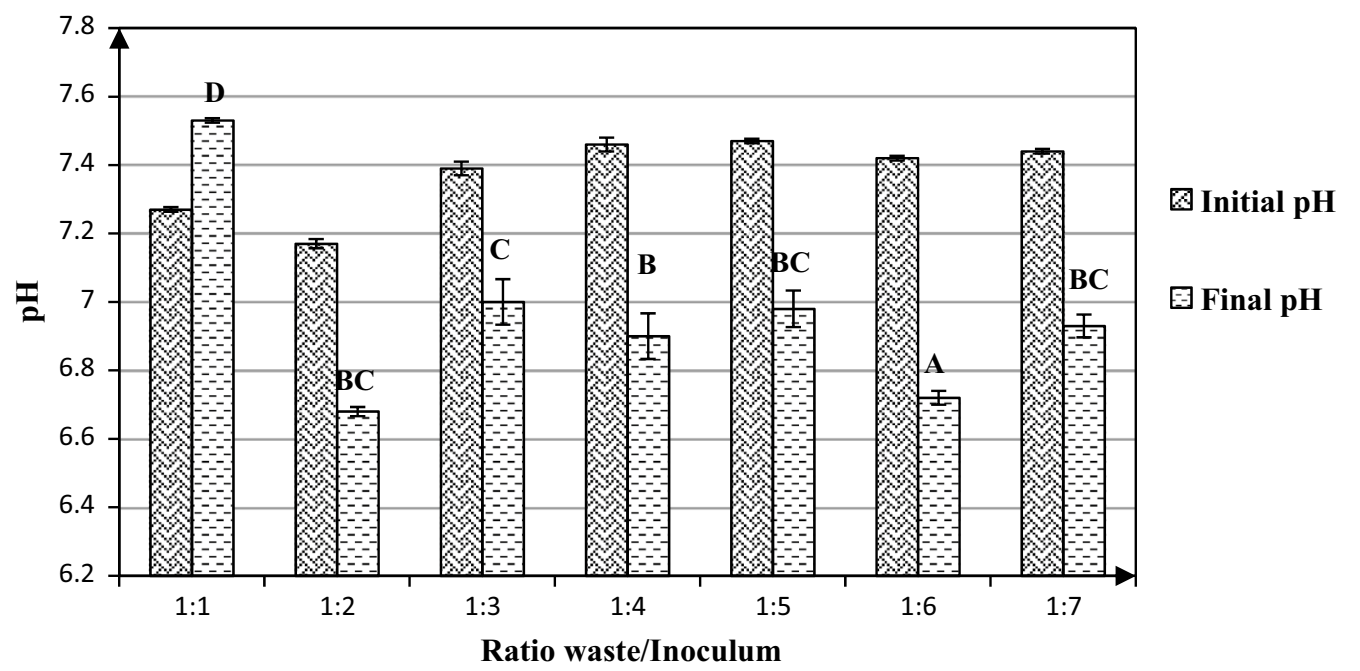

Fig. 5 Comparison of the evolution of $\mathrm{pH}$ by different ratios of waste/inoculum. Mean values originated from three independent replications. Horizontal bars represent standard deviations. Means with different letters indicate significant differences (Duncan's test $p<0.05$ )

the biogas and methane production. The maximum biogas volume produced is using the lowest ratio of waste and inoculum (1:7) but the highest methane percentage in the biogas is reached by the highest ratio (1:1). Therefore, from a qualitative point of view, the high percentage of methane is obtained for the highest ratio 1:1; however, from a quantitative point of view, the largest production is obtained from the lowest ratio 1:7. The lesson learnt is that the ratio waste/inoculum was clearly the most important parameters for the treatment of chicken manure and the related production of green energy in Egyptian agricultural farms.

\section{Abbreviations \\ $\mathrm{C} / \mathrm{N}$ : Carbon-to-nitrogen ratio; $\mathrm{KOH}$ : Potassium hydroxide; $\mathrm{CH}_{4}$ : Methane; TS: Total solids; VS: Volatile solids; FM: Fresh matter; pH: Potential of hydrogen; VFAs: Volatile fatty acids; p: Probability value.}

\section{Authors' contributions}

$\mathrm{OE}, \mathrm{MS}$ designed the experiments; MS performed the experiments; OE, MS, $\mathrm{MR}, \mathrm{OZ}$ and LL wrote this manuscript. All authors read and approved the final manuscript.

\section{Author details}

1 Biochemistry and Biotechnology Laboratory, Mohamed First University, Oujda, Morocco. ${ }^{2}$ Agricultural Engineering Research Institute, Agricultural Research Center, Nadi El Said St., Giza, Egypt. ${ }^{3}$ Ecology, Water and Environment Laboratory, Mohamed First University, Oujda, Morocco. ${ }^{4}$ Applied Biology and Pathology Laboratory, Abdelmalek Essaâdi University, Tetouan, Morocco.

${ }^{5}$ Faculty of Sciences Semlalia, Cadi Ayyad University, Marrakech, Morocco.

\section{Acknowledgements}

We deeply thank Mrs Hicham Elasri and A. Fauzi Taybi for their technical support to produce this work.

\section{Competing interests}

The authors declare that they have no competing interests.

\section{Availability of data and materials}

All data generated and analyzed during this study are included in this manuscript.

\section{Consent for publication}

All authors have approved to submit this work to Chemical and Biological Technologies in Agriculture. They declare that there is no conflict of interest in relation to the submission of the article.

\section{Ethics approval and consent to participate}

Not applicable.

\section{Funding}

Not applicable.

\section{Publisher's Note}

Springer Nature remains neutral with regard to jurisdictional claims in published maps and institutional affiliations.

Received: 13 January 2018 Accepted: 23 July 2018

Published online: 28 August 2018

\section{References}

1. Hosny FA. Poultry sector-country review (Egypt). FAO Animal Production and Health Division: Italy; 2006.

2. FAOSTAT, Food and Agriculture Organization of the United Nations, Statistics division, live animals, Egypt, Stocks, Chickens. http://www.fao. org/faostat/en/\#data/QA. Accessed 30 July 2018.

3. Arifin B, Bono A, Janaun J. The transformation of chicken manure into mineralized organic fertilizer. J Sustain Sci Manag. 2006;1 (1):58-63.

4. Elasri O, Afilal ME. Potential for biogas production from the anaerobic digestion of chicken droppings in Morocco. Int J Recycl Org Waste Agric. 2016;5:195-204.

5. Ganoulis J. Risk analysis of wastewater reuse in agriculture. Int J Recycl Org Waste Agric. 2012;1(1):1-9.

6. Kostadinova G. Sanitary hygienic assessment of drinking water from underground source at a pig farm. Agric Sci Technol. 2013;5(4):448-54. 
7. Jun $\mathrm{P}$, Gibbs $\mathrm{M}$, Gaffney K. $\mathrm{CH}_{4}$ and $\mathrm{N}_{2} \mathrm{O}$ emissions from livestock manure. In: Penman J, Kruger D, Galbally I, editors. Good practice guidance and uncertainty management in national greenhouse gas inventories. Hayama: IPCC Task Force on National Greenhouse Gas Inventories; 2002. p. 321-81.

8. Radwan AF, Hanafy AA, Elhelw M, El-Sayed AE-HA. Retrofitting of existing buildings to achieve better energy-efficiency in commercial building case study: hospital in Egypt. Alex Eng J. 2016;55(4):3061-71.

9. Chen Y, Cheng JJ, Creamer KS. Inhibition of anaerobic digestion process: a review. Bioresour Technol. 2008;99(10):4044-64.

10. El Asri O, Ramdani M, Latrach L, Haloui B, Ramdani M, Afilal ME. Comparison of energy recovery after anaerobic digestion of three Marchica lagoon algae (Caulerpa prolifera, Colpomenia sinuosa, Gracilaria bursapastoris). Sustain Mater Technol. 2017;11:47-52.

11. El Asri O, Ramdani M, Latrach L, Haloui B, Mohamed R, elamin Afilal M. Energetic valorization of Nador lagoon algae and proposal to use it as a means of elimination of the eutrophication in this lagoon. Ecol Eng. 2017;103:236-43.

12. Budzianowski WM. A review of potential innovations for production, conditioning and utilization of biogas with multiple-criteria assessment. Renew Sustain Energy Rev. 2016;54:1148-71.

13. Perlatti B, Forim MR, Zuin VG. Green chemistry, sustainable agriculture and processing systems: a Brazilian overview. Chem Biol Technol Agric. 2014;1(1):5.

14. Kim Y, Kawahara N, Tsuboi K, Tomita E. Combustion characteristics and NOX emissions of biogas fuels with various $\mathrm{CO}_{2}$ contents in a micro cogeneration spark-ignition engine. Appl Energy. 2016;182:539-47.

15. Calise F, Cremonesi C, di Vastogirardi GN, d'Accadia MD. Technical and economic analysis of a cogeneration plant fueled by biogas produced from livestock biomass. Energy Procedia. 2015;82:666-73.

16. Van Aarle IM, Perimenis A, Lima-Ramos J, de Hults E, George IF, Gerin PA. Mixed inoculum origin and lignocellulosic substrate type both influence the production of volatile fatty acids during acidogenic fermentation. Biochem Eng J. 2015;103:242-9.

17. Perimenis A, et al. Metabolic profile of mixed culture acidogenic fermentation of lignocellulosic residues and the effect of upstream substrate fractionation by steam explosion. Biomass Convers. Biorefinery. 2015;6(1):25-37.

18. Elasri O, Mahaouch M, elamin Afilal M. The evaluation and the development of three devices for measurement of biogas production. Phys Chem News. 2015;75:75-85.

19. Kafle GK, Kim SH, Sung Kl. Ensiling of fish industry waste for biogas production: a lab scale evaluation of biochemical methane potential (BMP) and kinetics. Bioresour Technol. 2013;127:326-36.

20. El Asri O, Hafidi I, elamin Afilal M. Comparison of biogas purification by different substrates and construction of a biogas purification system. Waste Biomass Valorization. 2015;6(4):459-64.

21. Ergüder T, Güven E, Demirer G. Anaerobic treatment of olive mill wastes in batch reactors. Process Biochem. 2000;36(3):243-8.

22. APHA. Standard methods for the examination of water and wastewater. 21st ed. Washington, D.C: American Public Health Association and Water Environment Federation; 2005.

23. Bouteleux $\mathrm{C}$, et al. Escherichia coli behavior in the presence of organic matter released by algae exposed to water treatment chemicals. Appl Environ Microbiol. 2005;71(2):734-40.

24. Abouelenien F, Fujiwara W, Namba Y, Kosseva M, Nishio N, Nakashimada Y. Improved methane fermentation of chicken manure via ammonia removal by biogas recycle. Bioresour Technol. 2010;101(16):6368-73.

25. Yenigün O, Demirel B. Ammonia inhibition in anaerobic digestion: a review. Process Biochem. 2013;48(5-6):901-11.

26. Wittmann C, Zeng A-P, Deckwer W-D. Growth inhibition by ammonia and use of a pH-controlled feeding strategy for the effective cultivation of Mycobacterium chlorophenolicum. Appl Microbiol Biotechnol. 1995:44(3-4):519-25.
27. Rinzema A, Boone M, van Knippenberg K, Lettinga G. Bactericidal effect of long chain fatty acids in anaerobic digestion. Water Environ Res. 1994;66(1):40-9.

28. Zaccheria F, Mariani M, Ravasio N. The use of rice bran oil within a biorefinery concept. Chem Biol Technol Agric. 2015;2(1):23.

29. Hwu C-S, Tseng S-K, Yuan C-Y, Kulik Z, Lettinga G. Biosorption of long-chain fatty acids in UASB treatment process. Water Res. 1998;32(5):1571-9.

30. Pereira MA, Sousa DZ, Mota M, Alves MM. Mineralization of LCFA associated with anaerobic sludge: kinetics, enhancement of methanogenic activity, and effect of VFA. Biotechnol Bioeng. 2004;88(4):502-11.

31. Mata-Alvarez J, Macé S, Llabrés P. Anaerobic digestion of organic solid wastes. An overview of research achievements and perspectives. Bioresour Technol. 2000;74(1):3-16.

32. Cirne DG, Paloumet $X$, Björnsson L, Alves MM, Mattiasson B. Anaerobic digestion of lipid-rich waste-effects of lipid concentration. Renew Energy. 2007;32(6):965-75.

33. Brown D, Li Y. Solid state anaerobic co-digestion of yard waste and food waste for biogas production. Bioresour Technol. 2013;127:275-80.

34. Hansen KH, Angelidaki I, Ahring BK. Anaerobic digestion of swine manure: inhibition by ammonia. Water Res. 1998;32(1):5-12.

35. Li Y, Park SY, Zhu J. Solid-state anaerobic digestion for methane production from organic waste. Renew Sustain Energy Rev. 2011;15(1):821-6.

36. Neves $L$, Oliveira R, Alves MM. Influence of inoculum activity on the biomethanization of a kitchen waste under different waste/inoculum ratios. Process Biochem. 2004;39(12):2019-24.

37. Nazaitulshila R, Idris A, Harun R, Wan Azlina WAKG. The influence of inoculum to substrate ratio on the biochemical methane potential of fat, oil, and grease in batch anaerobic assays. Energy Sources Part Recovery Util Environ Eff. 2015;37(6):590-7.

38. Chynoweth DP, Turick CE, Owens JM, Jerger DE, Peck MW. Biochemical methane potential of biomass and waste feedstocks. Biomass Bioenergy. 1993;5(1):95-111.

39. Yoon Y-M, Kim S-H, Shin K-S, Kim C-H. Effects of substrate to inoculum ratio on the biochemical methane potential of piggery slaughterhouse wastes. Asian Australas J Anim Sci. 2014;27(4):600-7.

40. Li C, Champagne P, Anderson BC. Evaluating and modeling biogas production from municipal fat, oil, and grease and synthetic kitchen waste in anaerobic co-digestions. Bioresour Technol. 2011;102(20):9471-80.

41. Kalyuzhnyi SV. Batch anaerobic digestion of glucose and its mathematical modeling. II. Description, verification and application of model. Bioresour Technol. 1997;59(2-3):249-58.

42. Li Y, Zhang R, Chen C, Liu G, He Y, Liu X. Biogas production from co-digestion of corn stover and chicken manure under anaerobic wet, hemi-solid, and solid state conditions. Bioresour Technol. 2013;149:406-12.

43. Krylova NI, Khabiboulline RE, Naumova RP, Nagel MA. The influence of ammonium and methods for removal during the anaerobic treatment of poultry manure. J Chem Technol Biotechnol. 1997;70(1):99-105.

44. Zhou J, et al. Biogas production and microbial community shift through neutral $\mathrm{pH}$ control during the anaerobic digestion of pig manure. Bioresour Technol. 2016;217:44-9.

\section{Submit your manuscript to a SpringerOpen ${ }^{\circ}$ journal and benefit from:}

- Convenient online submission

- Rigorous peer review

- Open access: articles freely available online

- High visibility within the field

- Retaining the copyright to your article

Submit your next manuscript at $\boldsymbol{\nabla}$ springeropen.com 